POLITYKA ENERGETYCZNA - ENERGY POLICY JOURNAL

$2018 \uparrow$ Volume $21 \uparrow$ Issue $4 \uparrow 155-178$

DOI: $10.24425 / 124506$

Zbigniew KaszTelewicz ${ }^{1}$, Antoni Tajduś ${ }^{1}$, Marek CAŁA ${ }^{1}$, Miranda PTAK ${ }^{2}$, Mateusz SiKorA ${ }^{1}$

\title{
Strategic conditions for the future of brown coal mining in Poland
}

ABSTRACT: The national power industry is based primarily on its own energy mineral resources such as hard and brown coal. Approximately $80 \%$ of electrical energy production from these minerals gives us complete energy independence and the cost of its production from coal is the lowest in comparison to other sources. Poland has, for many decades had vast resources of these minerals, the experience of their extraction and processing, the scientific-design facilities and technical factories manufacturing machines and equipment for own needs, as well as for export. Nowadays coal is and should be an important source of electrical energy and heat for the next 25-50 years, because it is one of the most reliable and price acceptable energy sources. This policy may be disturbed over the coming decades due to the depletion of active resources of hard and brown coal. The conditions for new mines development as well as for all coal mining sector development in Poland are very complicated in terms of legislation, environment, economy and image. The authors propose a set of strategic changes in the formal conditions for acquiring mining licenses. The article gives a signal to institutions responsible for national security that without proposed changes implementation in the legal and formal process it, will probably not be possible to build next brown coal, hard coal, zinc and lead ore or other minerals new mines.

KEYWORDS: mining, brown coal, hard coal, coal-based power engineering, mining-energetic doctrine, formal-legal condition, energy security

${ }^{1}$ AGH University of Science and Technology in Kraków; e-mail: kasztel@agh.edu.pl, tajdus@agh.edu.pl, cala@ agh.edu.pl, sikoram@agh.edu.pl

${ }^{2}$ Wrocław University of Technology; e-mail: miranda.ptak@pwr.edu.pl 


\section{Introduction}

Taking a decision as to the future of electrical energy generation from brown coal is becoming more and more urgent. This stems from both the mining and geological situation in terms of the depleting available resource base as well as political and investment conditions. The factors which now exert the greatest impact on the situation are mainly:

a) The programme for the brown coal sector under development, which is strictly in line with the government's plans for works on Poland's energy policy until 2050, the content of which should take the proposed solutions and their impact on the energy mix of Poland after 2030 into account. By the end of 2018, each EU member state is obliged to present the Integrated National Plan for Energy and Climate covering the period 2021-2030 for consultation to the European Commission (including the national target for RES in particular sectors and for individual technologies).

b) Another strategic document under development is Poland's Raw Materials Policy. This document will describe all mineral deposits in Poland in a detailed manner, including their valorisation. It should indicate the importance of brown coal for the security of the country and its protection.

At the same time, while the above-mentioned strategic documents are being elaborated, the formal and legal regulations should be changed in order to enable the development of the brown coal industry and the maintenance of brown coal in the Polish energy mix after 2030. The most important include:

a) Changes in the procedure of adopting studies of conditions and directions of spatial development, local plans of spatial development of communes in the area of the planned investment.

b) Streamlining of proceedings aimed at obtaining an environmental decision.

c) Streamlining of proceedings aimed at obtaining or extending mining licenses.

The climate and energy policy of the European Union currently has a significant impact on the use of conventional raw resources, including brown coal. An active dialogue with the European Union institutions seems quite necessary in order to negotiate solutions enabling the implementation of brown coal-based deposit projects for Poland. In particular, attention should be paid to the provisions included in:

a) the so-called winter package (e.g. a draft of the EU Governance regulation Article 23(4) limiting the possibility of support by power market mechanisms of new systems which emit above $550 \mathrm{~g} \mathrm{CO}_{2} / \mathrm{kWh}$ ),

b) the amendment of the EU ETS directive,

c) the BAT/BREF conclusions.

In order to ensure the development of brown coal in Poland, several conditions must be satisfied, including:

a) Taking a directional decision with regard to the role of brown coal in the national energy mix in the long-term perspective, including a directional indication of new brown coal based 
fuel-energy complexes (hereinafter referred to as "complexes") the implementation of which is planned within a given time limit.

b) Implementation of a specially developed mechanism ensuring the economic predictability of investments in new complexes.

c) Finishing the processes related to obtaining a concession for brown coal mining in selected locations.

d) The investors' decision to carry out investments in new complexes.

e) Granting legal protection to other prospective resources with a view to maintaining their future exploitation options.

f) Undertaking long-term actions targeted at improving the competitiveness of the brown coal sector.

Due to the restrictions on mechanisms supporting new investments in the energy sector provided by the European Union, it should be assumed that a dedicated support mechanism for such projects will differ from the standards generally accepted by the European Union and thus its implementation will be possible upon conducting a multidimensional dialogue process. Hence the role of the Government in negotiations with European institutions is key (Kasztelewicz and Ptak 2014; Ministry of Energy 2017).

\section{The key impact of brown coal mining on the national and regional policy}

In the course of the decision-making process shaping the future energy mix of the country one should take the key role of brown coal power plants and mines, both at the national and regional level into account because they:

a) ensure energy security,

b) ensure stable price levels for professional and commercial recipients,

c) provide stable and attractive jobs (there are around 23.5 thousand people currently employed directly in the brown coal industry, and after taking jobs in accompanying services into account, there are even up to around 100,000 (On the basis of the calculations of the Polish Mining Chamber of Industry and Commerce, one miner's workplace generates an average of four jobs in the field of agriculture and other sectors) people,

d) contribute to the development of road, railway, and public utility infrastructure, thus creating an integrated technically sustainable infrastructural landscape,

e) form industrial and urban centers,

f) retain in the country the revenue stream from energy sales (in the periods of both carrying out the investment and its operation):

$\checkmark$ stimulating internal demand, the development of the services sector, construction, education, etc., 
acting as a source of significant income from fees and taxes for provinces and communes, and improving the macroeconomic indices of the region.

\section{The performance forecast for existing complexes}

Brown coal resources in the currently exploited deposits enable maintaining a stable level of extraction and operation of complexes only until about 2030, while a decrease in extraction will take place already after 2020. Then, due to the depletion of the resource base, the process of phasing down the exploitation will commence. If new complexes are not constructed, in 2040-2045, the brown coal-based production capacities in Poland will fade away and the industry will be virtually liquidated. The gap in covering the demand for power and electrical energy in the National Power System (NPS) after 2030 will have to be supplemented on the basis of other technologies and fuels or imports of electrical energy from outside Poland.

This scenario is realistic, however, entirely unreasonable in light of the industry's achievements and development potential having the form of vast deposits of this fuel ensuring energy security for the country and high efficiency of electrical energy production. This situation will not only exert negative economic but also social consequences. The only agent able to prevent this scenario is the Government, which enjoys powers of deciding on the further development of the industry on the basis of exploitation of new deposits of the raw material. Bearing the above in mind, decisions with regard to the construction of new complexes should be taken as soon as possible. The absence of such decisions will translate into a significant gap in covering the demand for power and electrical energy in the PPS after 2030, which will have to be supplemented using other technologies and fuels or imports of electrical energy from outside Poland.

In Poland, brown coal is extracted in five open-cast mines:

The Bełchatów Brown Coal Mine and the Turów Brown Coal Mine owned by Polska Grupa Energetyczna Górnictwo i Energetyka Konwencjonalna (PGE GiEK SA),

Konin Brown Coal Mine and Adamów Brown Coal Mine forming part of the Zespół Elektrowni Pątnów-Adamów-Konin (ZE PAK SA), and Kopalnia Węgla Brunatnego Sieniawa Sp. z o.o.

The geological balance resources of brown coal (according to the Resource Balance for 2016, as at December 31,2016 ) amounts to $23,451.13$ million tons, of which the majority are steam coals $-23,450.49$ million tons, while the remaining 0.64 million tonnes are bituminous coals. In the past, briquettes and low-temperature carbonized coals were also documented. At present, all resources of briquette and low-temperature carbonized coals are considered to be steam coals. Geological balance resources in the managed deposits amount to $1,353.65$ million tons, which constitutes $5.77 \%$ of the geological balance resources. Industrial resources (according to the Resource Balance for 2016) in active plants amount to 1,047.74 million tons and the state of operational resources is about 1 billion tons. 
Brown coal resources in the deposits currently exploited by individual mines will make it possible to maintain a stable level of extraction only until 2020. Following this period, there a decrease in the mining potential of the existing mines will occur, and thus a decrease in the extraction and availability of brown coal as a fuel for the power industry. This state of affairs is shown in Figure 1.

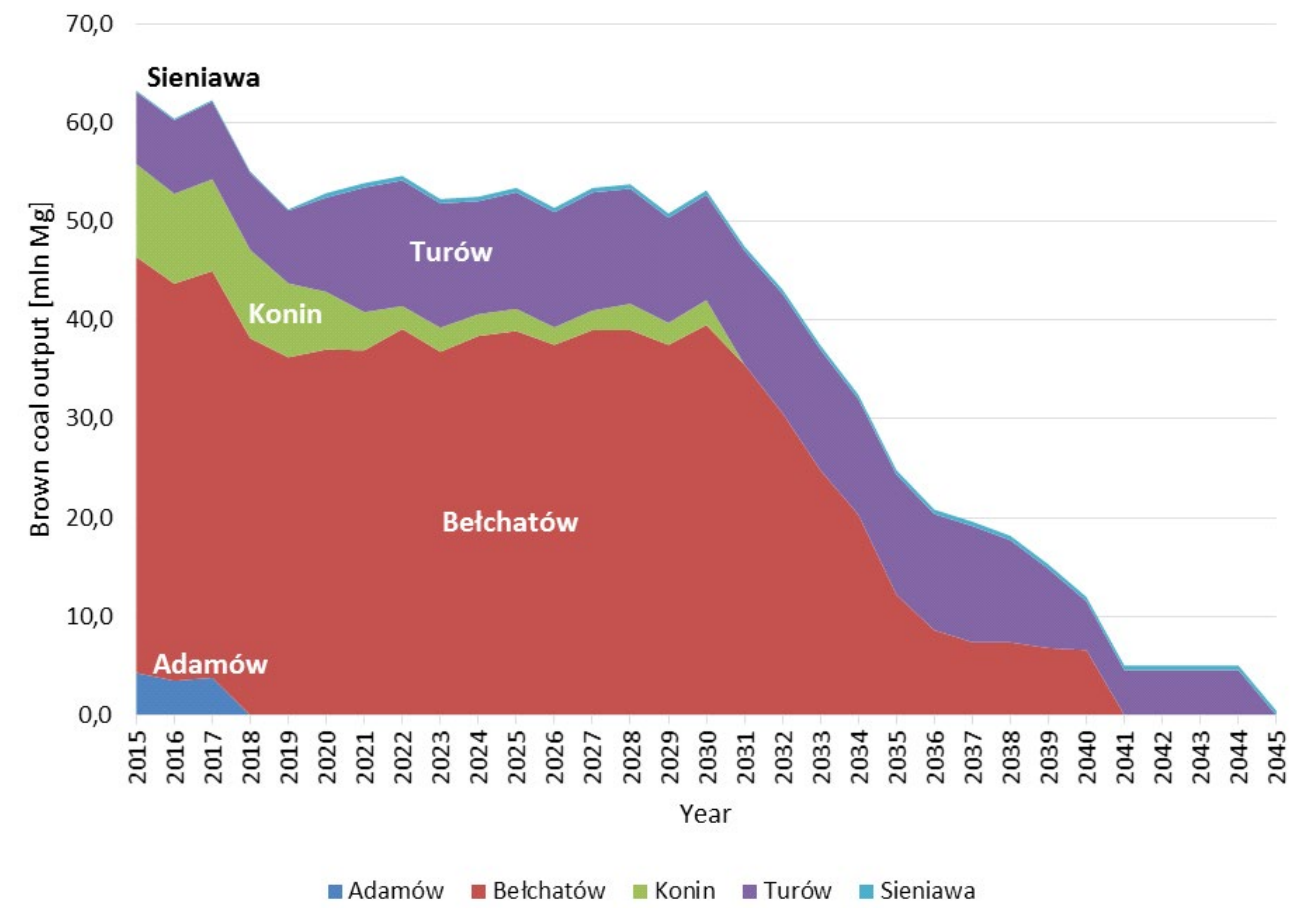

Fig. 1. Brown coal current output and output forecast - without additional mining licenses and new mining plants development (own study)

Rys. 1. Stan i prognoza wydobycia węgla brunatnego - bez uzyskania koncesji i budowy nowych kopalń

The investment process including the preparation and performing the construction of a new complex, i.e. a brown coal mine and a power plant connected with it, is somewhat complicated and long-lasting, and in the case of large deposits may take even 10-12 years. Bearing this in mind, decisions with regard to the construction of new complexes should be taken as soon as possible. 


\section{Characteristics of the national energy system}

When analyzing the future energy mix of Poland, it is necessary to take various conditions into account, both dependent on and independent of the country's mining and energy industry. The current state of the domestic power industry is the starting point for strategic conditions. In Poland, both brown coal and hard coal are not only the cheapest source of energy, but also the only one which makes us a self-sufficient country in terms of energy.

The characteristics of the National Power System (NPS) in the past years were as follows. In 2016, the installed capacity in the National Power System amounted to 41,396 MW, and the available capacity $-41,278 \mathrm{MW}$, which represented an increase of $2.4 \%$ and $3.8 \%$, respectively, in comparison with 2015. The average annual power demand amounted to 22,483 MW, with a maximum demand of $25,546 \mathrm{MW}$, which means an increase of $1.2 \%$ and a decrease of $1.8 \%$ in comparison with 2015. The ratio of available power to maximum power in 2016 remained at a similar level as in 2015 and amounted to $69.4 \%$ (increase by 0.6 percentage points in comparison with 2015).

The structure of electrical energy production in 2016 did not changed significantly in comparison with 2015. The vast majority of energy production is still based on conventional fuels, i.e. hard coal and brown coal - as shown in Table 1. In the analyzed period, the dynamics of growth of electrical energy production from RES has fallen in comparison to previous years, with the wind generation remaining the production leader in this segment. In 2016, electrical energy production in Poland amounted to approximately 162.6 TWh and was $0.53 \%$ higher than a year before, its consumption amounting to approximately 164.6 TWh, which was higher by 1.97 per cent. The balance of foreign electrical energy exchange amounted to plus 1,999 GWh in 2016, which means that energy imports were greater than exports.

share of individual RES in obtaining electrical energy from renewable sources in 2013-2015 is shown in table 2. The leader in the production of energy from RES are solid biofuels.

When analyzing data on the unit costs of electrical energy generation (Table 3 ) one should observe that brown coal is the cheapest source of electrical energy and an important factor stabilizing its price in the Polish power system. The cost of producing electrical energy from hard coal is over $30 \%$ higher than in the case of brown coal, and the cost of electrical energy sold from energy from wind or biomass is more than two times higher than energy from brown coal. The cost of solar energy is, on the other hand, over 5 times higher than the cost of energy from brown coal. It should be noted however that producing energy from wind, biomass, or solar energy is largely subsidized (Gabryś 2016; Kasztelewicz and Ptak 2014).

Renewable energy is characterized by unstable performance, both from solar and wind sources, and requires having flexible, that is, capable of immediate launching of power resources to secure the continuity of supply for customers. During the periods of overlapping (especially then) stoppages of both solar and wind RES it is necessary to use fully available coal, gas, or hydrogeneration sources (outside of Poland also nuclear energy). The experience of energy engi- 
TABLE 1. Production structure, national balance of flows in cross-border exchanges and power consumption in 2015-2016 [GWh] (based on Office for Energy Regulation 2017)

TABELA 1. Struktura produkcji, krajowe saldo przepływów fizycznych w wymianie transgranicznej oraz zużycie energii elektrycznej w latach 2015-2016 [GWh]

\begin{tabular}{|l|r|r|r|c|}
\hline \multicolumn{1}{|c|}{ Specification } & $2015[\mathrm{GWh}]$ & $2016[\mathrm{GWh}]$ & $\begin{array}{c}\text { Dynamics } \\
2016 / 2015 ; \\
2015=100\end{array}$ & $\begin{array}{c}\text { Percentage share } \\
\text { in electrical energy } \\
\text { production in 2016 }\end{array}$ \\
\hline $\begin{array}{l}\text { Total electrical energy production, } \\
\text { including: }\end{array}$ & 161,772 & 162,626 & 100.53 & \\
\hline Hard coal-powered power plants & 81,883 & 81,348 & 99.35 & 50.02 \\
\hline Brown coal-powered power plants & 53,564 & 51,204 & 95.59 & 31.48 \\
\hline Gas power plants & 4,193 & 5,776 & 137.75 & 3.55 \\
\hline Industrial power plants & 9,757 & 10,130 & 103.82 & 6.23 \\
\hline Hydroelectric power plants & 2,261 & 2,399 & 106.10 & 1.48 \\
\hline Wind farms & 10,041 & 11,623 & 115.76 & 7.15 \\
\hline $\begin{array}{l}\text { Other renewable sources; including solar } \\
\text { energy }\end{array}$ & 73 & 146 & 200 & 0.09 \\
\hline Foreign exchange balance & -334 & 1,999 & & \\
\hline Domestic energy consumption & 161,438 & 164,625 & 101.97 & \\
\hline
\end{tabular}

TABLE 2. Particular RES share in obtaining electrical energy from renewable sources in 2013-2015 [\%] (based on Office for Energy Regulation 2017)

TABELA 2. Udział poszczególnych nośników OZE w pozyskaniu energii ze źródeł odnawialnych w latach 2013-2015

\begin{tabular}{|l|c|c|c|}
\hline \multicolumn{1}{|c|}{ Specification } & 2013 [\%] & $2014[\%]$ & $2015[\%]$ \\
\hline Sold biofuels & 79.88 & 76.14 & 72.22 \\
\hline Solar energy & 0.29 & 0.43 & 0.52 \\
\hline Water energy & 2.45 & 2.31 & 1.82 \\
\hline Wind energy & 6.03 & 8.13 & 10.76 \\
\hline Biogas & 2.12 & 2.56 & 2.64 \\
\hline Fluid biofuels & 8.18 & 9.18 & 10.78 \\
\hline Geothermal energy & 0.22 & 0.25 & 0.25 \\
\hline Municipal solid waste & 0.39 & 0.45 & 0.46 \\
\hline Heat pumps & 0.44 & 0.55 & 0.56 \\
\hline
\end{tabular}

neers in Germany has allowed a system of brown coal-fired power plants with a capacity of up to 5,000 MW for launching within 30 minutes. This example shows that modern coal-fired power plants match the controllability of gas-fired power plants. In the contrast, unpredictability of the production of electrical energy from the wind or sun shows the period of warm a summer (August) 2015 , where out of 4,200 MW of the installed power in the wind energy only $100 \mathrm{MW}$ was 
TABLE 3. Technical unit costs of produced and sold electrical energy (Gabryś 2016)

TABELA 3. Jednostkowe koszty techniczne wytworzonej i sprzedanej energii elektrycznej

\begin{tabular}{|c|c|c|c|c|c|c|c|c|}
\hline \multirow{2}{*}{$\begin{array}{l}\text { Specification } \\
\text { Year }\end{array}$} & \multicolumn{4}{|c|}{$\begin{array}{l}\text { The unit technical cost of manufacturing } \\
\text { [PLN/MWh] }\end{array}$} & \multicolumn{4}{|c|}{$\begin{array}{l}\text { The unit cost of energy sold [PLN/ } \\
\text { MWh] }\end{array}$} \\
\hline & 2012 & 2014 & 2013 & $2015^{1)}$ & 2012 & 2014 & 2013 & $2015^{1)}$ \\
\hline Brown coal-fired power plant & 139.7 & 134.9 & 134.6 & 130.4 & 154.3 & 156.3 & 160.8 & 154.4 \\
\hline Hard coal-fired power plant & 212.5 & 183.9 & 199.3 & 172.3 & 250.8 & 205.3 & 227.5 & 192.1 \\
\hline Gas power plant & 303.1 & 261.0 & 372.2 & 241.2 & 324.1 & 286.9 & 405.9 & 264.0 \\
\hline Hydropower plant & 186.2 & 170.5 & 153.0 & 164.2 & 232.0 & 227.7 & 181.1 & 190.5 \\
\hline Wind farms & 208.0 & 227.8 & 222.1 & 210.9 & 361.1 & 367.4 & 365.0 & 348.8 \\
\hline $\begin{array}{l}\text { Power plant/Heat and power } \\
\text { plant - biomass }\end{array}$ & 446.1 & 361.6 & 405.6 & 367.9 & 463.7 & 412.7 & 451.1 & 379.0 \\
\hline
\end{tabular}

1) For three quarters of 2015.

actually operating! A similar situation occurred in the winter of 2016. One may pose a question: how to plan the work of the energy system. January 2017 in Germany, when windless weather occurred is also worth recalling. The country stood on the verge of a catastrophe. Even the old coal blocks were hurriedly "dusted off". The same problem applies to solar energy and biomass once they are in place, and once they are not. A good explanation of the wind farm performance is an example of a potential replacement of the Bełchatów Power Plant with a capacity of almost $5,400 \mathrm{MW}$ for wind farms. Assuming the use of $20 \%$ of wind farms - it is necessary to have wind power with an installed capacity of $20,000 \mathrm{MW}$, that is 10,000 wind turbines, each $2 \mathrm{MW}$. This means that many provinces should be built up with wind farms, and if there is no wind at all, Bełchatów Power Plants should be kept available!

\section{Environmental aspects related to the production of electrical energy on the basis of brown coal}

Despite numerous modernizations, opencast brown coal mining is still perceived as an industry that is not technologically advanced but excessively interfering with the natural environment. The need for significant improvements to the basic economic and image relations is of particular importance. New smart brown coal mines and power plants must be designed in the most optimal way and must be based on the most modern mining and generation systems, so as to make the production costs of the unit of energy from this fuel still competitive when compared to other energy products. The condition for meeting these expectations now and in the future is 
first and foremost the "flight forward", towards the improvement of innovative technologies and processes of mining and the combustion of brown coal fuels. The efficient and effective management of these processes is of importance along with the use of the most modern technical support tools, past expertise, and the qualifications of the engineering staff. The contemporary situation and future prospects for the operation of brown coal-based energy require a significant improvement in the attractiveness of this industry, its adaptation to the growing social, environmental, and economic expectations (Tajduś et al. 2014). One should realize that despite the many years of national energy corporations being present on the market, the positive and environmentally friendly image is somewhat unsuccessful. The industry does not have a "brand-ambassador" for the production of energy from stable domestic resources. Too little brand-building, education, and social activity does not help in transferring knowledge about the state of activities for environmental protection. As an industry, we should draw on experience of those whose products strongly interfere with the environment and who are still perceived as the leaders of pro-ecological activities.

\subsection{Emissions of sulphur, nitrogen oxides, dust, and $\mathrm{CO}_{2}$}

Brown coal-fired power stations have for years been complying with all increasingly demanding emission standards. Older power plants have been modernized, equipped with flue gas desulphurisation systems, $\mathrm{NO}_{\mathrm{x}}$ emission reduction systems, and high efficiency dedusting devices. The above situation is illustrated in Figures 2, 3, and 4 showing the emissions of $\mathrm{SO}_{2}, \mathrm{i} \mathrm{NO}_{\mathrm{X}}$ as well as dust in the years 1989-2016 in the Turów and Bełchatów power plants, i.e. in older generation power plants. In the Pątnów-Adamów complex, the reductions are not so as significant due to the lower emission threshold (Figures 2, 3, and 4).

In response to the forthcoming successive toughening of emission standards, which will be introduced after 2021 on the basis of the new edition of BAT Conclusions, all Polish coal-fired power plants (including those operating on brown coal) are expected to undergo extensive modernization in relation to emission-reducing devices.

The improvement of efficiency of electrical energy generation in coal-fired power plants, including brown coal, is also of significant environmental importance. The net efficiency has grown from around $35 \%$ for typical $200 \mathrm{MW}$ units, through $41.7 \%$ for the $858 \mathrm{MW}$ unit in Befchatów, up to $43.1 \%$ guaranteed for the ELT11 unit currently under construction at the Turów Power Plant. This improvement in efficiency has been achieved mainly due to the increase of parameters of fresh steam to the ultra-supercritical level (for ELT11 it is $28.5 \mathrm{MPa} / 600^{\circ} \mathrm{C}$ ) and the improvement of other elements limiting production losses.

Such significant improvement in efficiency means not only better use of primary energy in the fuel, but also proportional reduction of $\mathrm{CO}_{2}$ emission capacity. For example, the gross emission capacity of the new unit in Turów will be $822 \mathrm{kgCO}_{2} / \mathrm{MWh}$, while for the old $200 \mathrm{MW}$ units it was over $1000 \mathrm{kgCO}_{2} / \mathrm{MWh}$. These are of course higher values than those analogous for 
hard coal, but this is directly attributable to the physical and chemical properties of these fuels. Dependencies between the efficiency of electrical energy production and $\mathrm{CO}_{2}$ emission capacity is illustrated in Figure 5 (Kasztelewicz and Patyk 2015; Ministry of Energy 2017).

Intensive research and implementation works were carried out a few years ago in order to overcome the material problems for power plants operating with fresh steam at $700^{\circ} \mathrm{C}$. Such parameters would improve efficiency by a further several percentage points, and thus a further reduction of $\mathrm{CO}_{2}$ emission capacity. Bad publicity of the coal-fired power plants has recently slowed down the pace of this research, however one may assume that creating appropriate economic incentives for further improvement of the efficiency of the thermodynamic cycle in fossil-fuel power plants will again speed up the research and implementation.

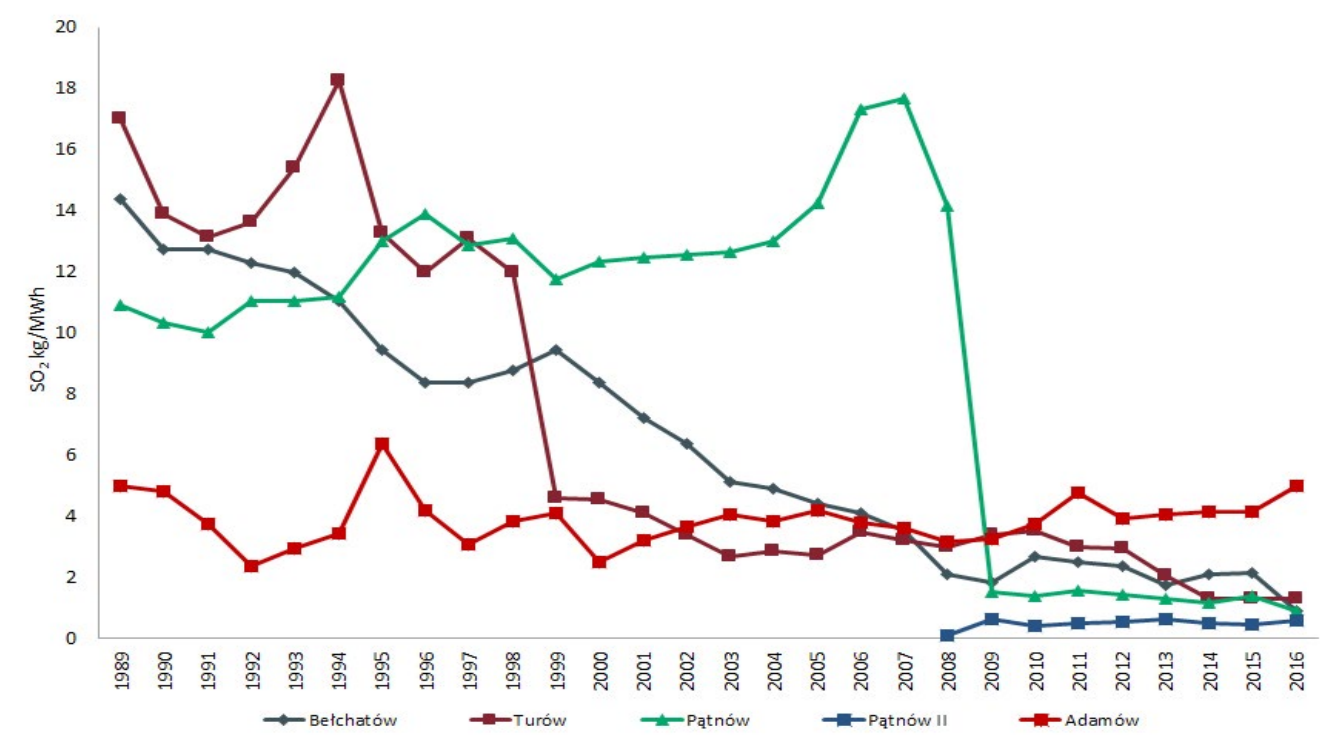

Fig. 2. Reduction of $\mathrm{SO}_{2}$ emission on the example of selected brown coal-based power plants (own study based on PGE GiEK SA data source)

Rys. 2. Spadek emisji $\mathrm{SO}_{2}$ na przykładzie wybranych elektrowni na węgiel brunatny

From the perspective of more and more troublesome issues with smog in most Polish urban agglomerations, one should note that the proportions of pollutant emissions - based on PM10 and benzopyrene - between modern power plants and low emission sources (mainly home furnaces) indicate a marked difference in favor of the power plant. The replacement of domestic coal furnaces with electric heating will significantly reduce low emission thus improving air quality, and at the same time will increase the demand for electrical energy by raising and stabilizing production in coal-fired power plants, using both hard coal and brown coal. 


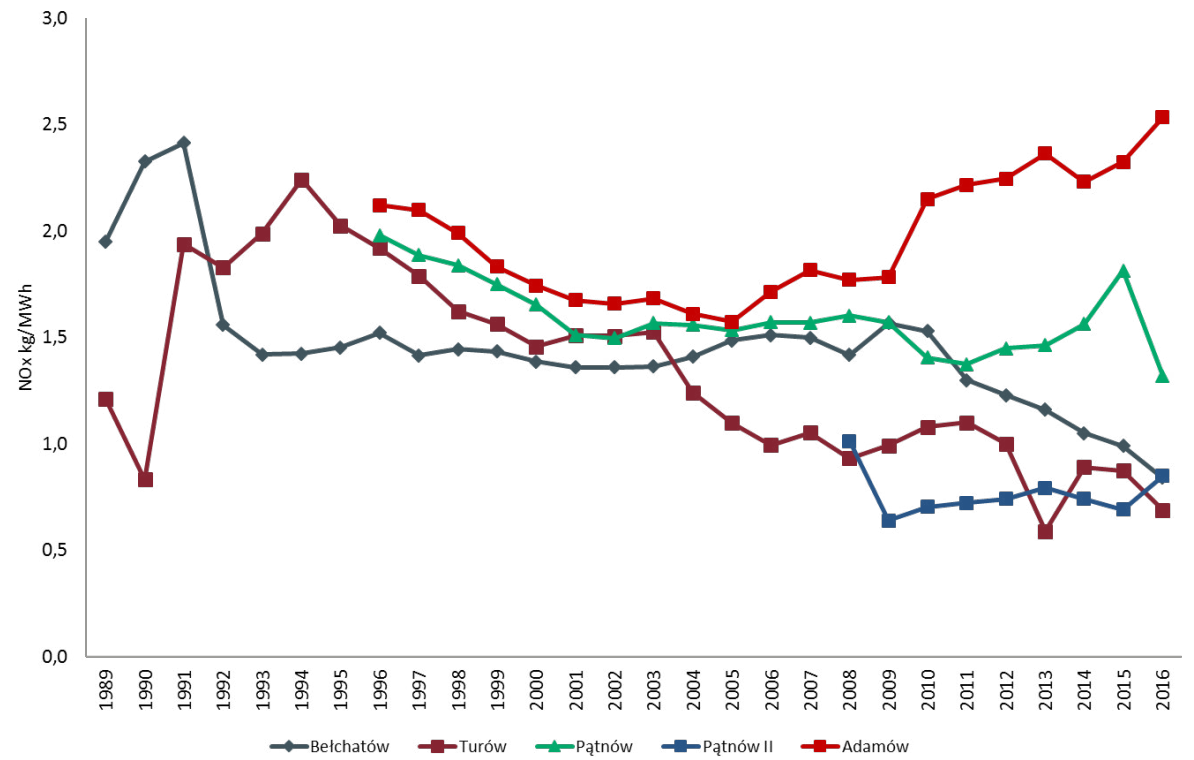

Fig. 3. Reduction of $\mathrm{NO}_{\mathrm{x}}$ emission on the example of selected brown coal-based power plants (own study based on PGE GiEK SA data source)

Rys. 3. Spadek emisji $\mathrm{NO}_{\mathrm{x}}$ na przykładzie wybranych elektrowni na węgiel brunatny

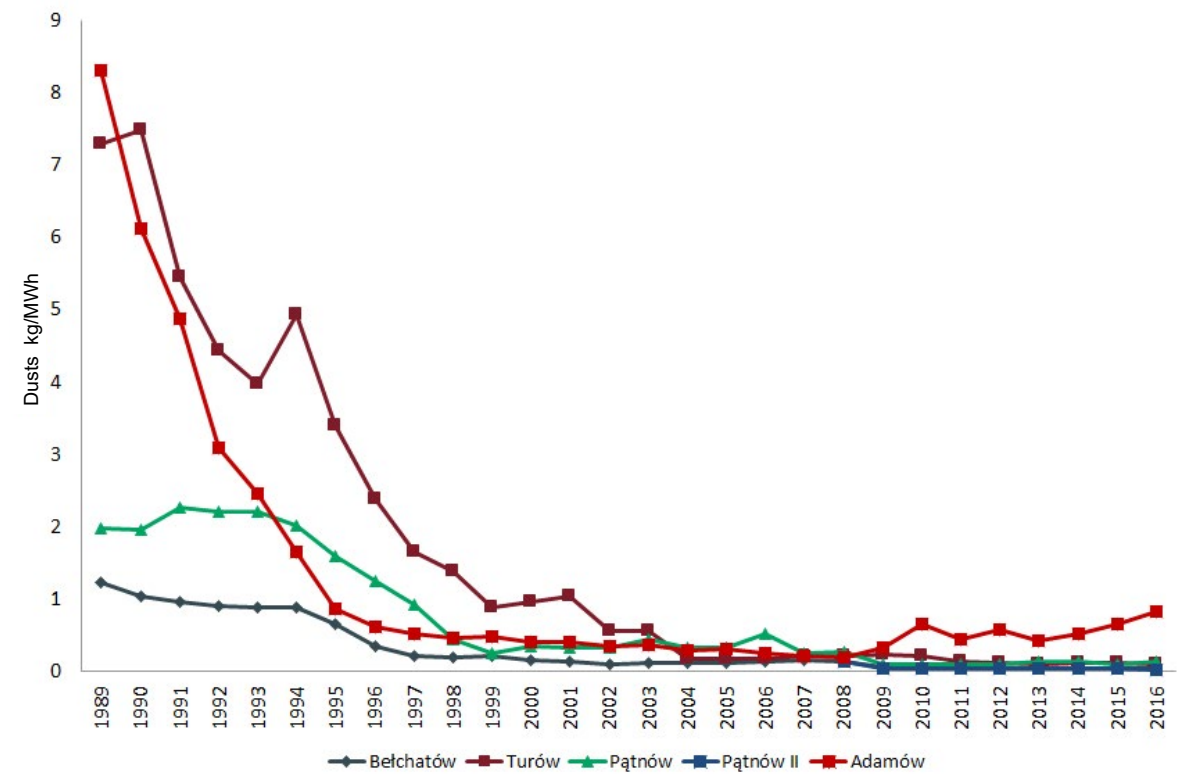

Fig. 4. Reduction of dust emission on example of selected brown coal-based power plants (own study based on PGE GiEK SA source data)

Rys. 4. Spadek emisji pyłu na przykładzie wybranych elektrowni na węgiel brunatny 


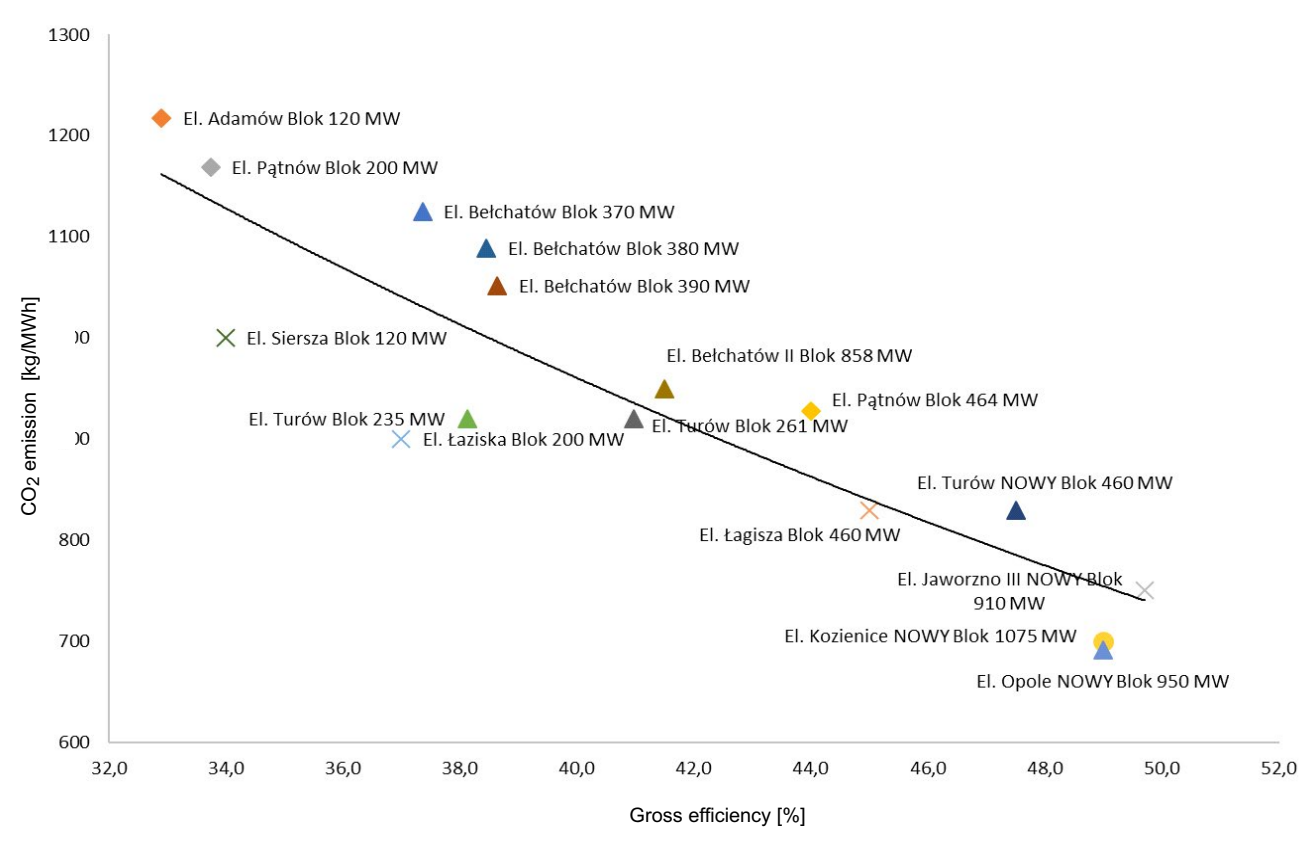

Fig. 5. $\mathrm{CO}_{2}$ emission depending on the production efficiency (own study based on PGE GiEK SA data source)

Rys. 5. Zależność emisji $\mathrm{CO}_{2}$ od sprawności wytwarzania

\subsection{Reclamation of post-mining areas}

Brown coal mining is inextricably linked to the transformation of the landscape. In the case of this fuel, we usually have to deal with large-scale opencast mines, in which such transformations reach a scale greater than in other sectors. This is caused by the necessity of building external dumps of considerable size and open pit excavations up to $300 \mathrm{~m}$ deep. Therefore, the process of reclamation or revitalization is a very important aspect of this industry. The process of reclamation and revitalization of the land transformed by mining activity, despite the fact that it is long-lasting and requires a lot of organizational and financial effort on the part of the entrepreneur, if properly conducted, brings surprisingly beneficial effects. For many years, the mining industry has been returning post-mining areas, the value of which, from the point of view of biological and economic value, appears as similar and sometimes much higher than the original one. The returned lands gain a new "identity" and their designation meets social needs and expectations. At the same time, it creates great opportunities to make the post-mining area, and thus the entire region attractive, by creating functions of a supra-regional scope on the basis of transformations created as a result of mining operations. Polish mines perform reclamation works with high standards at the European level and implement them respecting the applicable law and taking the needs of the local communities into account (Tajduś et al. 2014). 
Table 4 presents data on land management in individual mines, taking the quantity of land purchased and returned including nontransformed and recultivated land as at December 31, 2016 into account.

TABLE 4. Land management in individual mining plants from the beginning of their activities until the end of 2016 (own study)

TABELA 4. Gospodarka gruntami w poszczególnych kopalniach od początku ich działalności do końca 2016

\begin{tabular}{|c|c|c|c|c|c|c|}
\hline \multirow{2}{*}{ Specification } & \multicolumn{2}{c|}{ ZE PAK SA } & \multicolumn{2}{c|}{ PGE GiEK SA } & \multirow{2}{*}{ Total } \\
\cline { 2 - 6 } & Adamów & Konin & Bełchatów & Turów & \\
\hline \multicolumn{2}{|c|}{ Acquired [ha] } & 6,341 & 14,462 & 11,322 & 5,340 & 37,465 \\
\hline $\begin{array}{c}\text { Transferred- } \\
\text { Sold }\end{array}$ & Total [ha] & 3,836 & 8,643 & 3,898 & 1,728 & 18,457 \\
\hline \multirow{2}{*}{ Including: } & $\begin{array}{c}\text { Non-transformed } \\
\text { [ha] }\end{array}$ & 293 & 2,507 & 2,324 & 278 & 5,402 \\
\cline { 2 - 6 } & Recultivated [ha] & 3,543 & 6,136 & 1,574 & 1,802 & 13,055 \\
\hline \multicolumn{2}{|c|}{ Assets at the end of 2016 [ha] } & 2,505 & 8,519 & 7,424 & 3,260 & 19,008 \\
\hline
\end{tabular}

The first is the SA mine, which performed over 50\% of the reclamation works for the entire industry. The second is PAK KWB Adamów SA, followed by the mines of PGE GiEK SA Branch KWB Bełchatów and Turów. The main sites of the Konin and Adamów mines result from the fact that they are typical multi-pit mines exploiting relatively small and shallow brown coal deposits. The situation is different in the case of deep mines, such as the workings of the Bełchatów and Turów Mines, where it is necessary to build significant external dumps, due to the need to remove large overburden quantities in order to provide access to the coal seam. In this case, the entire reclamation process is multi-stage and long-lasting.

\section{Prospects for the development of new brown coal deposits in the context of electrical energy demand by 2050}

Brown coal mining is an industry which has over the years developed very good techniques and technologies for the exploitation and use of land related to mining activities, as well as management and organization systems. One may quite responsibly say that this industry has changed dramatically, having introduced new standards in its operations in comparison with the situation from 20-25 years ago. Over the last years, a huge modernization effort has been made, the latest technical and organizational solutions as well as a number of efficiency programs, 
which undoubtedly bring about a profit in the form of competitive advantage of brown coal in comparison with other sources of primary energy, have been implemented.

The development strategy of opencast brown coal mining in Poland in the first half of the $21^{\text {st }}$ century was developed by analyzing possible scenarios in active mining and energy basins as well as in new regions with significant resources of this fuel. Table 5 presents the list of strategic resources together with the date of their potential development and the possible level of extraction.

TABLE 5. List of strategic deposits with indication of their potential development date and possible production level (own study)

TABELA 5. Wykaz złóż o charakterze strategicznym wraz ze wskazaniem terminu ich potencjalnego zagospodarowania i możliwego poziomu wydobycia

\begin{tabular}{|l|c|c|c|c|}
\hline $\begin{array}{c}\text { Name of the deposit/deposit } \\
\text { complex }\end{array}$ & $\begin{array}{c}\text { Recognition } \\
\text { category }\end{array}$ & $\begin{array}{c}\text { Geological } \\
\text { resources } \\
{[\mathrm{m} \text { tons] }}\end{array}$ & The developing prospect & $\begin{array}{c}\text { Possible output } \\
\text { level } \\
\text { [m tons/year] }\end{array}$ \\
\hline Złoczew & $\mathrm{B}+\mathrm{C} 1$ & 611 & until 2030 & $18-20$ \\
\hline Gubin (Gubin 2) & $\mathrm{B}+\mathrm{C} 1+\mathrm{C} 2$ & 1,624 & until 2030 & $18-20$ \\
\hline Ościsłowo & $\mathrm{C} 1$ & 50 & until 2030 & 3 \\
\hline Dęby Szlacheckie & $\mathrm{C} 1$ & 113 & until 2030 & 4 \\
\hline Oczkowice & $\mathrm{C} 1+\mathrm{C} 2$ & 966 & until 2050 & $10-18$ \\
\hline Legnica & $\mathrm{B}$ do D2 & 14,522 & until 2050 & $30-40$ \\
\hline
\end{tabular}

The effect of these analyses is a variant industry strategy having the form of three scenarios for the development of brown coal mining in Poland by 2050:

$\checkmark$ the pessimistic (non-development) scenario, which assumes the use of only those brown coal deposits for which the mines currently hold or are planning to extend the mining licenses,

$\checkmark$ the realistic (base) scenario, which assumes the continuation of the development of this mining on the basis of satellite deposits of the currently operating mines (Ościsłowo) and the development of prospective resources of the Łódź region (Złoczew) and Lubuskie region (Gubin 2),

$\checkmark$ the optimistic (development) scenario, which assumes continuation of development of brown coal mining on the basis of satellite deposits in operating mines (Dęby Szlacheckie) and creating new mining basins on the basis of prospective deposits of the western region (Legnica) and the Wielkopolska region (Oczkowice).

Nevertheless, the deposits included in this optimistic scenario should be subject to strict protection due to their strategic nature and, in the event that a need arises to develop the sector in the long term, they should first be taken into account. If, for various reasons, the future exploitation of these fields is not possible, other deposits of a similar capacity should be taken into account (e.g. Torzym, Gostyń) (Kasiński 2008).

The implementation of the Strategy for the brown coal industry (apart from the pessimistic scenario) will enable continuation of the industry's operations in the $21^{\text {st }}$ century in the form of the development and continuation of extraction and production of electrical energy from brown 
coal. A summary of production parameters for the pessimistic, realistic, and optimistic scenarios is presented in Table 6 (Tajduś et al. 2014).

TABLE 6. A summary of individual scenarios production parameters: pessimistic, realistic, and optimistic (own study)

TABELA 6. Łączne zestawienie parametrów produkcyjnych scenariuszy: pesymistycznego, realnego oraz optymistycznego

\begin{tabular}{|c|c|c|c|c|c|c|}
\hline \multirow{3}{*}{ Years } & \multicolumn{2}{|c|}{ The pessimistic scenario } & \multicolumn{2}{|c|}{ The realistic scenario } & \multicolumn{2}{|c|}{ The optimistic scenario } \\
\hline & total coal output & $\begin{array}{c}\text { total production } \\
\text { of electrical } \\
\text { energy }\end{array}$ & total coal output & $\begin{array}{c}\text { total production } \\
\text { of electrical } \\
\text { energy }\end{array}$ & total coal output & $\begin{array}{c}\text { total production } \\
\text { of electrical } \\
\text { energy }\end{array}$ \\
\hline & {$[\mathrm{m}$ tons $]$} & $\begin{array}{c}\text { [thousands of } \\
\text { GWh] }\end{array}$ & {$[\mathrm{m}$ tons $]$} & $\begin{array}{c}\text { [thousands of } \\
\text { GWh] }\end{array}$ & {$[\mathrm{m}$ tons $]$} & $\begin{array}{c}\text { [thousands of } \\
\text { GWh] }\end{array}$ \\
\hline 2020 & 52.9 & 47.6 & 52.9 & 47.6 & 52.9 & 47.6 \\
\hline 2025 & 53.4 & 48.1 & 56.3 & 50.7 & 60.3 & 54.3 \\
\hline 2030 & 53.1 & 47.8 & 60.7 & 54.6 & 76.7 & 69.0 \\
\hline 2035 & 24.8 & 22.3 & 55.9 & 50.3 & 61.8 & 55.6 \\
\hline 2040 & 12.0 & 10.8 & 47.0 & 42.3 & 62.8 & 56.5 \\
\hline 2045 & 0.5 & 0.4 & 35.5 & 31.9 & 65.5 & 58.9 \\
\hline 2050 & 0.0 & 0.0 & 35.0 & 31.5 & 76.0 & 68.4 \\
\hline
\end{tabular}

In contrast, Figure 6 shows the possible extraction of brown coal according to individual scenarios.

Brown coal mining may and should be the guarantor of the energy security for Poland for many decades of the 21 st century. The increase in the role of coal mine lies in its processing for liquid and gaseous fuels, including synthesis gas and hydrogen as well as in the production of briquettes or coal dust.

\section{Strategic conditions for the future of brown coal mining in Poland}

The parallel development of Poland's policy on raw materials is a very important element of the new mining and energy doctrine. This means that both the Energy Policy and Raw Materials Policy should either constitute a single document or be a document elaborated simultaneously so as to maintain the highest possible level of coherence of these studies. The raw materials policy, which will form the basis for a social discussion on the definition of which raw materials are stra- 


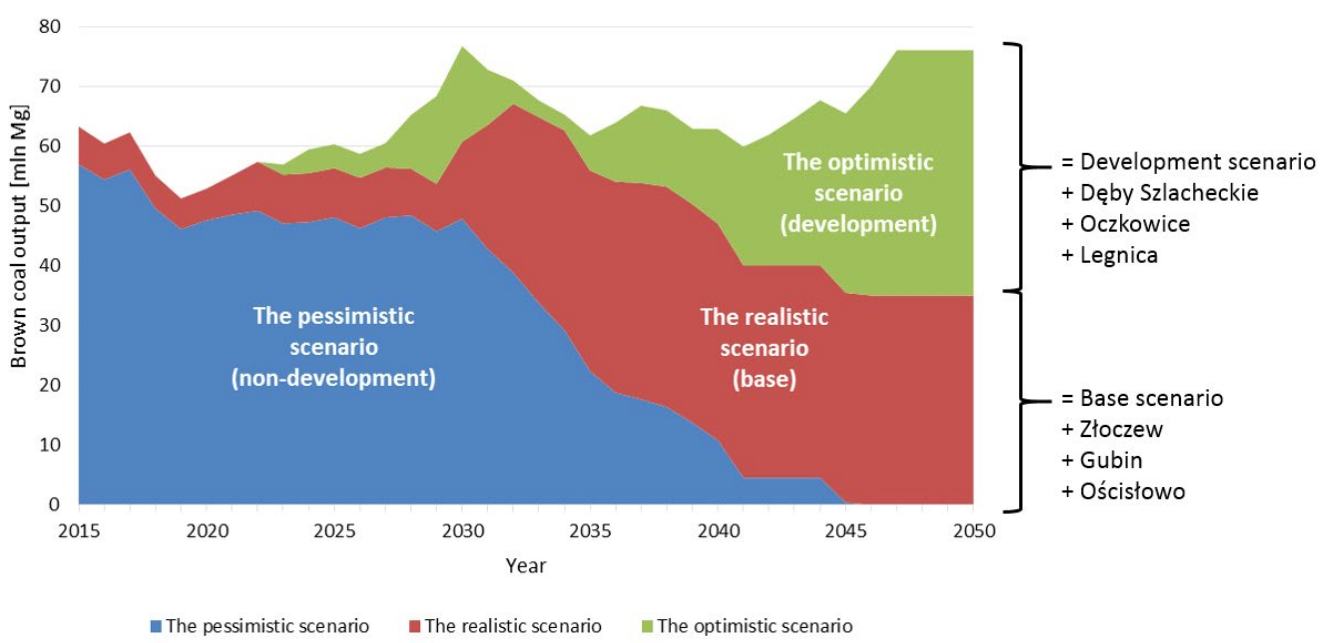

Fig. 6. Brown coal production according to individual scenarios of development up to 2050 [millions of tonnes] (own study)

Rys. 6. Wydobycie węgla brunatnego według poszczególnych scenariuszy rozwoju do roku 2050 [mln ton]

tegic for the country and in which regions, must take a clear stance on the deposits covered by the maximum protection - as the strategic resources. Currently, many scenarios and declarations related to the development of deposits in various locations exist, however, there are no indications as to which of them should be given priority. At the same time, the deposits of specific raw materials should be secured against them being blocked, and the inhabitants of these areas should be provided within a predetermined time with a fair compensation for the purchase of real property. One should also consider compensation in the form of an exploitation allowance, to which the property owners in the mining area would be entitled, as compensation for the nuisance caused by the neighboring industry (Jurdziak et al. 2014).

Another important issue is the effective protection of mineral deposits for mining activities of future generations. The process of securing strategic mineral deposits should be assigned an appropriate priority in relation to other forms subject to legal protection. Unfortunately, this self-evident argument is not sufficiently articulated in the legal provisions, so as to effectively protect mineral deposits. This applies, among others, to energy resources, which means that for future generations valuable deposits may be lost in terms of their economic use through their further infrastructure development. These deposits should be included in spatial development plans and secured for their use through the implementation of planned projects as public purpose investments of national importance, which would be a guarantee that the area in question may not be managed in any different manner. The current disclosure of existing deposits in planning documents in both the study of spatial development and directions that in local spatial development plans in no way protects these deposits. Furthermore, the area of such deposit occurrence may be built-up or developed in a different way. The country from which we could draw from experience is Austria, where 
miners, ecologists, local government officials, and politicians have been discussing on how to designate strategic deposits for development in the $21^{\text {st }}$ century for a number of years. The discussion having lasted many years, the fields for development have been designated and at this stage no group of opponents is able to block the development of new mines.

It is rather obvious that not all deposits will be developed. There are different priorities set for energy resources and for other deposits of non-energy raw materials. Poland should valorize various mineral deposits and identify strategic deposits as well as adopt a simplified path for those to obtain mining licenses. Miners have been requesting a list of strategic fields to be developed for 10 years, and for 20 they have been demanding the statutory protection of deposits prior to surface development as well as are asking for the streamlining of formal and legal rules governing the expansion and construction of new mines. The situation of the construction of motorways or facilities for Euro 2012 was quite similar - only the adoption of the Special Act allowed for the construction of these facilities. Another, but important issue is imposing mines various types of taxes and public levies constituting revenues of the state budget on 30 coal, as well as budgets of territorial self-government units in the territories where they operate. The excessive financial burden constitutes from $15 \%$ to over $30 \%$ of additional costs of coal mining (Kasztelewicz et al. 2016).

Positive directions of activities should include initiatives, including those originated by the government, in limiting decarbonization and stopping the liquidation of the hard coal and brown coal industries. The creation of a single department dealing with energy and subordination to the single policy of raw materials policy seem to be just right. The development of the Hard Coal Program and the Brown coal Program covering the years 2017-2030 with a perspective up to 2050 constitutes a good forecast for the upcoming years. However, this does not aid the bad situation in the brown coal industry caused by the depletion of deposits currently exploited by the mines, while the launch of new mines encounters huge formal and legal difficulties. Without the launch of new brown coal mines after 2020, the liquidation of this industry will be phased in. One should also recall that this industry, since 1989 , has not needed, nor has it received any public aid.

Therefore, for the development of the Polish mining and energy industry based on the cheapest fuel, namely coal, making a strategic change in the country's economic policy with respect to the mining industry is proposed. Many of the following proposals, suggestions, or conclusions formed at congresses or scientific and technical conferences were presented by the industry, the world of science as well as the social factor. Some of these solutions have already been adopted for implementation as tasks for ministries in governmental documents, such as the National Spatial Development Concept 2030 of 2011, the Energy Policy of Poland until 2030 adopted for implementation in 2009, or the draft of the Energy Policy until 2050 of 2015 and many other documents. Unfortunately, the mere adoption in planning documents does not yet mean implementation. Responsible ministries have not developed the required documents and, as a result, the construction of new mines or the extension of the existing ones becomes almost impossible under the present conditions (Kasztelewicz and Patyk 2015; Kasztelewicz et al. 2016a, 2016b).

For the development of the brown coal industry, strategic actions should be as follows:

A. Development of a new Raw Materials Policy along with statutory security for coal deposits (brown coal) before their surface development. Securing strategic brown coal deposits as 
well as other mineral resources should be part of a long-term raw materials policy at the national level. The aim of such a policy should be to provide entrepreneurs access to raw materials, while caring for the state of the natural and social environment at every stage of its development as well as the current and long-term economic security of Poland. This document should contain such issues as:

$\checkmark$ developing an institutional framework for the development and implementation of the state's policy on raw materials,

$\checkmark$ rendering support to works related to the exploration of new deposits in Poland,

$\checkmark$ monitoring the state of resources of mineral deposits and maintaining current databases,

$\checkmark$ updating the long-term resource balance,

$\downarrow$ good practices enabling the reconciliation of brown coal mining and the Nature 2000 program,

$\checkmark$ recognition of investments related to brown coal deposits as public purpose investments of national importance,

$\checkmark$ drawing up brown coal exploitation plans taking the existing infrastructure, occurrence of the protected nature areas as well as river basin management and regular updating thereof into account,

- rules for protection and tools which will compensate to municipalities for e.g. losses caused by being deprived of a possibility to build areas with the strategic deposits covered by maximum protection.

B. Developing a new Energy Policy until 2050 which would focus on the priority of using domestic energy resources against imported fuels and technologies. Poland's Energy Policy should indicate which energy resources are to be made available to the national energy sector and at what time. Such a principle is applied by all those countries in the world which have their own energy resources. In the first place they use their own fuels, and only then, imported fuels.

C. Drawing up a list of strategic brown coal resources for economic use in the $21^{\text {st }}$ century. For the protection of documented brown coal resources, for the purposes of spatial plans, to determine the ranking and valorization of recognized coal deposits (brown coal) is necessary. Due to the large number of documented brown coal deposits (over 90), a need to draw up a ranking of strategic deposits has arisen, which due to their parameters and location have the greatest potential for economic development. Such deposits, because of their strategic nature, should be subject to maximum protection. The manner and scope of protection should be specified in a separate document on Poland's Raw Materials Policy. The creation of such a document is necessary and constitutes one of the activities defined in the specific objectives of the Program related to securing access to new brown coal deposits. The above ranking will ensure the future economic use of highly valorized deposits on a determined time scale.

D. The improvement of proceedings related to the adoption of studies on the conditions and directions of spatial development and local spatial development plans in the area of mining investments. In practice, the obligation provided for by the Polish law to take mineral de- 
posits and their protection in studies of conditions and directions of spatial development of communes and in local spatial development plans into account is not implemented. This stems mostly from the resistance of the local community, which translates into the reluctance of the commune authorities to consider deposits in planning documents. Including deposits in planning documents is necessary to obtain a mining license. Moreover, where the borders of documented deposits are not disclosed in planning documents, effective protection of deposits prior to land development is not allowed, thus making it difficult or impossible to undertake operations in the future. Therefore, one may state that in the existing legal status, the decisions on the possibilities of managing strategic resources for the whole country are decided by the commune authorities. The solution would be the government's acceptance of selected investments as strategic public-purpose investments of national importance and the initiation of dialogue from the governmental level with representatives of communes.

E. Improvement of proceedings aimed at obtaining an environmental decision for mining investments. The other area which also poses a great obstacle to the positive completion of the license obtaining procedure are environmental proceedings. It is worth noting that it is necessary for the investor to include all infrastructure elements which interfere with the project (e.g. the required reconstructions of roads, power lines) along with assessment of the influence they exert on the environment already at the stage of obtaining an environmental permit. This is difficult also because of the fact that it requires the preparation of detailed projects and only on their basis is it possible to present the required information objectively.

This range is not entirely consistent with the Deposit Development Project, which constitutes the basis for defining the subject of mining activity. The Regulation on detailed requirements for deposit development projects of April 24, 2012 does not take the provisions on environmental impact assessments into account. The Deposit Development Project is the first, basic planning document of the undertaking and is carried out by the investor before proceeding to drawing up of the report on environmental impact. The regulation requires presenting activities necessary in the scope of environmental protection, including exploitation technology ensuring the reduction of negative environmental influences, but does not prescribe that these actions should allow for issuing decisions on environmental conditions. For this reason, at the stage of preparing the Deposit Development Project, matters related to environmental protection, including environmental protection, are not discussed in detail. Next, upon issuance of the environmental decision, the provisions of the Deposit Development Project do not include later issued environmental conditions included in the report. Therefore, to Deposit Development Project documents and an environmental impact report are drawn up, which for a single project often indicate entirely different solutions, all of which is connected by means of a license decision. The license decision is based strictly on the Deposit Development Project and environmental decision issued on the basis of the report. As a result, there may be a requirement to design environmental compensation, reduce the funnel of depression, or abandon the operation of some conflicting resources. An additional factor that complicates the entirety of proceedings is the fact that obtaining a decision on environmental conditions is conditioned by entering the planned investment into the water 
management plan. This plan is created for a period of 6 years and cannot be changed for the duration of its validity.

F. Issuing of coal mining licenses for the entire period of mineral extraction, up to the forecast period of resource utilization (as is the case with rather pragmatic Czechs).

G. Improvement of the process of obtaining mining licenses by the statutory development of new formal and legal rules for the construction of new mines for strategic resources modelled on the motorway construction act. This should primarily apply to those deposits which, due to their potential, have a significant impact on the energy security of the country. The authority over including a given deposit into the list of strategic deposits should be exercised by the Minister of Energy. The changes also concern legal solutions, which in the current shape allow commune authorities to block the proceedings aimed at obtaining a license. According to Article 23 of the Mining and Geological Law (hereinafter: PGiG) section (2a), the granting of a license requires an agreement with the commune head (mayor, president) competent for the place of performing the intended activity based on Article 7 of the Act, which sets forth the principle of not violating the designation of the property. Therefore, it requires carrying out all activities which will result in a change of land designation in the local spatial development plans (or the studies on the conditions and directions of spatial development, in the absence of the local spatial development plan).

$\mathrm{H}$. A detailed analysis of the scope and size of the public charges paid by mining entrepreneurs should be made for purposes of development of mining in Poland. Public charges are regulated on the basis of numerous acts. A lack of consistent and stable inter-ministerial policy in the area of public and legal charges and taxes was observed (Kasztelewicz and Ptak 2014).

I. Continuing the modernization of the Polish power industry. Domestic power engineering is to a large extent, decapitalized (and so are the transmission lines). Therefore, Poland should accelerate the modernization of the national coal power industry through convincing current and future investors about the financial viability of building a new power plant. Poland should accelerate works on introducing the so-called power market which will ensure profitability of the built modern power plants, modelled on solutions applied in many EU countries. The current communications of the Ministry of Energy about works on the power market are heading in the right direction.

J. Support from the authorities at every decision-making level is related to the development of brown coal deposits key throughout the entire process of implementation of projects, starting from the granting of licenses, until the completion of reclamation and development of post-mining areas. This is related not only to the need to create convenient formal and legal conditions for carrying out mining activity, and in the final phase, reclamation, but also to initiate activities aimed at raising awareness and knowledge in the society on the importance of mineral resources (including brown coal) for the development of the economy. Where there is no acceptance from the local community, all plans related to carrying out the mining activity in the case of brown coal but also other minerals may be effectively blocked. The currently observed Public Relations (PR) for mining, which is extremely negative, especially in terms of brown coal mining, requires extensive measures to promote achievements of the 
mining sector in the field of clean technologies and environmental protection, as well as possible opportunities for the development of not only the region, but also the country. Regional authorities should appoint expert teams composed of representatives of self-government and local communities, the world of science, administration and industry, to exchange views (as in the German model). In order to change the image, the coal industry should start a long-lasting dialogue with the public. Be a transparent partner, showing responsible actions aimed at achieving strategic goals while respecting other protected values at every stage.

Without the above discussed changes in the attitude to the state mining and energy policy and without formal and legal changes, there is little likelihood of building mines of brown coal, hard coal, or other minerals, such as zinc and lead ores much needed in Poland. All activities should be targeted at this one goal so that Poland, now a producer, would not become an importer of minerals, with job and lives of our citizens located outside the country.

\section{Summary}

Coal mining may and should be Poland's energy guarantor for many decades of the $21^{\text {st }}$ century. With this raw material one is able to continue to produce the cheapest electrical energy, not only in the present, but also in the future. The fact of underestimating the role of this raw material in the development of the country remains incomprehensible. The phenomenon that has been building up in recent years is the lack of social acceptance for mining and energy investments, and for open-cast mines in particular. The blame should be a large extent attributed to the "black PR", associated with the lack of reliable information on the nature and impact of this method of exploitation on the surrounding environment. This means that at present electrical energy from coal, and especially from brown coal, is perceived by the society and ecological organizations as the most environmentally unfriendly and causing a negative transformation of the landscape. However, it is time to speak out and present facts that put mining in a positive light. These are thousands of hectares of land that has been recultivated, managed and returned in a significantly better condition than those temporarily taken up for purposes of mining activities. At the same time, the development of brown coal mining is a synonym of work stability for thousands of Poles, increased comfort of life, and a guarantee of searching for newer technologies. At this point, it also should be emphasized that the essence of brown coal mining lies in our energy security which in turn is inextricably linked with the sovereignty of the state. The subject of Poland's energy security should be discussed above political divisions. The mining and energy companies are responsible for safety, but so are the legislative and executive authorities, both at the municipal, provincial, and national levels. 


\section{References}

Gabryś, H. 2014/2015/2016. Conference materials - unpublished works.

JURDZIAK et al. 2014 - JURDZIAK, L., KAWALEC, W. and WoŹNIAK J. 2014. Monography: The impact of the cost of buying $\mathrm{CO}_{2}$ emission allowances on the price of electrical energy in Poland. Consequences for the economy and society. Ed. Tomasz Szulc. Warsaw: Fundacja Energetyka-Bezpieczeństwa-Rozwój, $175 \mathrm{p}$.

KASIŃSKI, J. 2008. The future of brown coal-based mining and energy in Poland and Europe. The Polish Geological Institute - National Research Institute, Warsaw, pp. 1-7.

Kasztelewicz, Z. and PtaK, M. 2014. Public charges and taxes paid by the mining industry in Poland. Brown Coal no. 4/89.

KASZTELEWICZ, Z. 2015/2016/2017: Conference materials - unpublished works.

KASZTELEWICZ Z. and PATYK, M. 2015. The modern and efficiently coal power plants strategic challenge for Polish (Nowoczesne i sprawne elektrownie węglowe strategicznym wyzwaniem dla Polski). Polityka Energetyczna - Energy Policy Journal vol. 18, iss. 4, pp. 45-59 (in Polish).

KAsZtelewicz et al. 2016a - KAsZTelewicz Z., PtAK M. and SiKOra M. 2016a. Milestones of Polish energy doctrine for the development of lignite industry in the 21-st century in Poland (Kroki milowe polskiej doktryny energetycznej dla rozwoju branży wegla brunatnego w XXI wieku w Polsce). Polityka Energetyczna - Energy Policy Journal vol. 19, iss. 4, pp. 5-19 (in Polish).

Kasztelewicz et al. 2016b - KaszTelewicz Z., Ptak M. and Sikora M. 2016b. A government task as a formal and legal instrument in the procedure for obtaining a license for brown coal mining. Scientific Papers of the Institute for Mineral Resources and Energy, The Polish Academy of Sciences no. 96, pp. 119-131.

TAjduŚ et al. 2014 - TAJduŚ, A., KaCZOrowski, J., KaszTelewicz, Z., CZAJA, P., CAŁA, M., BRYJA, Z. and ŻUK, St. 2014. Brown coal - an offer for the Polish energy sector. The possibility of developing brown coal mining in Poland until 2050. The Mining Committee of the Polish Academy of Sciences, Krakow.

\section{Strategiczne uwarunkowania dla przyszłości górnictwa węgla brunatnego w Polsce}

\section{Streszczenie}

Krajowa energetyka oparta jest w głównej mierze na własnych surowcach energetycznych takich jak węgiel kamienny i brunatny. Produkcja ponad $80 \%$ energii elektrycznej z tych kopalin daje nam pełną niezależność energetyczną, a koszty produkcji energii z tych surowców są najmniejsze w stosunku do innych technologii. Polska posiada zasoby tych kopalin na wiele dziesiątków lat, doświadczenie związane z ich 
wydobyciem i przeróbką, zaplecze naukowo-projektowe oraz fabryki zaplecza technicznego produkujące maszyny i urządzenia na własne potrzeby, a także na eksport. Węgiel jest i winien pozostać przez najbliższe 25-50 lat istotnym źródłem zaopatrzenia w energię elektryczną i ciepło, gdyż stanowi jedno z najbardziej niezawodnych i przystępnych cenowo źródeł energii. Polityka ta w okresie następnych dekad może być zachwiana $z$ powodu wyczerpywania się udostępnionych zasobów węgla. Uwarunkowania dla budowy nowych kopalń, a tym samym dla rozwoju górnictwa w Polsce są bardzo złożone zarówno pod względem prawnym, środowiskowym, ekonomicznym, jak i wizerunkowym. Autorzy proponują zmiany, które rozwiązywałyby problemy w przedmiocie uzyskiwania koncesji wydobywczych. Artykuł sygnalizuje instytucjom odpowiedzialnym za bezpieczeństwo Polski, że bez wprowadzenia zaproponowanych istotnych zmian w procesie formalnoprawnym jest mało prawdopodobne, aby wybudowano, tak potrzebne kopalnie węgla brunatnego, kamiennego, rud cynku i ołowiu czy innych kopalin.

SŁOWA KLUCZOWE: górnictwo, węgiel brunatny, węgiel kamienny, energetyka węglowa, doktryna górniczo-energetyczna, uwarunkowania formalno-prawne, bezpieczeństwo energetyczne 
